\title{
PERCEIVING AND DEALING WITH CULTURE SHOCK: THE STUDY OF CHINESE INDONESIAN-LANGUAGE STUDENTS
}

\author{
Wang Qun, Syihabuddin, Yeti Mulyati, Vismaia S. Damaianti \\ Universitas Pendidikan Indonesia, Bandung, Indonesia
}

\begin{abstract}
semiya123@hotmail.com; syihabuddin@upi.edu; yetimulyati@upi.edu; vismaia@upi.edu
\end{abstract}
First draft received: 03 April 2018 Accepted: 31 June 2018 Final proof received: 25 August 2018

\begin{tabular}{l} 
First draft received: 03 April 2018 Accepted: 31 June 2018 Final proof received: 25 August 2018 \\
Abstract \\
This study reports culture shock issues such as pragmatic failures, social anxiety or loss of motivation \\
encountered by international students, and specifically focuses on Chinese Indonesian-language \\
students during study abroad in Indonesia. The data were collected through in-depth interviews and \\
participant observations and were analyzed using qualitative approach. A total of eight Chinese \\
students responded to the research that specifically stressed culture shock symptoms and the influence \\
in respect to intercultural communicative competence. The findings put forward that students of this \\
study had all experienced culture shock in view of intercultural communication, which could lead to \\
inconvenience living in Indonesia. The results indicate that before entering a new cultural environment, \\
it is very important to prepare as much beforehand as possible, especially for foreign language learners \\
in host countries. The researcher proposed several recommendations that certain encouragement and \\
support from teachers, media and method development from educational institutions, and a confident \\
attitude from oneself should be provided and built as a solution for students who need to deal with \\
culture shock problems. \\
Keywords: Culture shock, Chinese Indonesian-language students, study abroad, intercultural \\
communicative competence \\
To cite this paper (in APA style): \\
Qun, W., Syhabuddin, Mulyati, Y., Damaianti, V. S. (2018). Perceiving and Dealing with Culture Shock: \\
the Study of Chinese Indonesian-language Students. Indonesian Journal of Education, 11(1), 18-28. \\
doi: http://dx.doi.org/10.17509/ije.v11i1.12390 \\
\hline \hline
\end{tabular}

\section{INTRODUCTION}

In recent years, more and more students choose to go abroad to receive higher education. It is believed that study abroad is a worthy investment which not only enhances learners' foreign language communicative competence, but also is precious learning experience which is significantly different (Chen \& Zimitat, 2006). Empirical research has examined gains in oral fluency (Freed, 1995; Segalowitz \& Freed, 2004), pragmatic comprehension (Taguchi, 2008), and sociolinguistic skills (Barron, 2006) in second language acquisition during study abroad. However, it is important to note that students do not study language exclusively. They also attend social and cultural activities in the foreign community. Because language and culture are inseparable, learning a foreign language well means not only mastering the pronunciation, grammar, words and idioms, but also means learning the ways in which their language reflects the ideas, customs, and behavior of their society, and learning to understand their "language of the mind" (Huang, 2014). The culture learning process could be both positive and passive, for example, active learning in class and forced assimilation in community. It has been researched that by emerging oneself in a study abroad environment, students will need to learn about the behavioral style and beliefs of local people, and also acquire the social skills of the host culture (Rinehart, 2002; Yang, Webster \& Prosser, 2011).

Numerous studies show that nearly all of the study abroad students have encountered an array of acculturative stressors, including the language barrier, educational environment, sociocultural situations, discrimination, loneliness, and practical or lifestyle stressors (Lin \& Yi, 1997; Smith \& Khawaja, 2011). "No matter for what length of time, (the study abroad students) are responding not just to one event, but to a series of events and experiences" (Naysmith \& Corcoran, 2001) which are so different from their own and some of which are quite "shocking" to them, that the term "culture shock" is used to refer to these events and experiences (Hu, 2008). 
Culture shock is one of the common experiences by students abroad (Zhang, 2014). Culture shock is a well-known term used to define the initial experiences of immersion in an unfamiliar culture (Lombard, 2014). It was first used by the anthropologist Kalervo Oberg in 1954 and was defined as "the anxiety which results from losing all familiar signs and symbols of social intercourse". In recent years, researchers have proposed more findings on culture shock. Amongst them, Guinapa (1998) pointed out that culture shock is "the physical and emotional discomfort one suffers when coming to live in another country or a place different from the place of origin. This term expresses the lack of direction, the feeling of not knowing what to do or how to do things in a new environment, and not knowing what is appropriate or inappropriate."

To illustrate culture shock's influence, logically we need to ask, "What is culture?" The word "culture" was defined by British scholar E. B. Tylor as "a complex whole which includes knowledge, belief, art, law, morals, custom, and any other capabilities and habits acquired by man as a member of society" (Tylor, 1871). The American anthropologist Peacock provided his perspective that culture is "the taken-for-granted but powerfully influential understandings and codes that are learned and shared by members of a group" (Peacock, 1988). Moving to a new culture, study abroad students experience a multitude of problems affecting their communication competence (Chapdelaine \& Alexitch, 2004; Charles \& Stewart, 1991; Lewthwaite, 1996). Culture impacts on communication at a number of levels (Liddicoat, 2009). In other words, communication is never culture-free (Cetinavci, 2012). Communicative competence is a prerequisite for the successful development of a professional (Spencer \& Spencer, 1993), a demonstrated area (or areas) of successful communication activity on the basis of acquired tools and strategies of verbal communication supported by linguistic and language skills (Lukyanovaa, Daneykina, \& Daneikina, 2015).

More specifically, communicative competence is influenced or constituted by ability for language use and communication as a form of social interaction. An emerging idea about has been that, even if contextualized and linguistically adjusted, communication may not be sufficient unless it is accompanied by multidimensional cultural awareness supposed to lead to a relationship of acceptance where self and other are trying to negotiate a cultural platform satisfactory to all parties involved (Guilherme, 2000). Such ideas engendered the notion of intercultural communicative competence, i.e. the knowledge, motivation and skills to interact effectively and appropriately with members of different cultures (Wiseman, 2002).

Culture shock can be studied in many aspects such as linguistics, psychology, and anthropology. This current research attempted to investigate how culture shock impacted on Chinese Indonesian-language students' intercultural communicative competence in the light of they are language major students. For example, intercultural communication sometimes breaks down in real-life conversations, not because of the students' errors in syntax as a non-native speaker, or their inaccurate pronunciation in the target language, but because of their pragmatic incompetence in cultural understandings, which leads to pragmatic failure. In other words, they may be unable to use language effectively in order to achieve a specific purpose and to understand language in context. Another example is, in intercultural communication, a student may know the literal meaning of an utterance, but fail to understand its contextual meaning, or fail to accurately understand the speaker's intended force, which is particularly normal and unavoidable in Asian culture (Huang, 2014).

Therefore, the primary purpose of this research is generally to seek to ascertain the following questions: first, whether Chinese Indonesian-language students were suffering from culture shock in view of intercultural communication when studying abroad in Indonesia? Second, how they might typically perceive and deal with culture shock? In addition, the researcher went on to explore some of the implications on what teachers and students should do to prevent culture shock before entering a new cultural environment.

\section{METHOD}

To address the research questions, the researcher adopted qualitative approach, more specifically qualitative case study. The qualitative data were collected by using in-depth interviews and participant observations. The data were collected to explore issues of culture shock, its influence in respect to intercultural communicative competence, and participants' reaction and responding solutions to deal with it. The interview was semi-structured, which means it had a general outline but allowed for flexibility within that in order to gain a detailed picture of a respondent's beliefs about, or perceptions or accounts of, a particular topic (Smith, Harré \& Langenhove, 1995). There were two sessions of interviews with an interval of 3 months (from October to December, 2017). The participant observations data were acquired from both class attendance and outdoor activities of the researcher (from October to November, 2017). Participants' classroom performance was noted and evaluated by researcher and another Chinese Indonesian language teacher from the perspective of intercultural communicative competence, which embodied the relatively formal communicative performance. Meanwhile, outdoor intercultural communication performance was noted as informal communicative performance. Eight Chinese Indonesianlanguage students took part in the research while they were studying in an Indonesian university.

\section{Research techniques}

The in-depth interviews were conducted on October $8^{\text {th }}$, when participants had studies in Indonesia for over a month. The interview questions were developed based on Mumford's Culture Shock Questionnaire (1998) and aforementioned findings on students' communicative behaviors. This semi-structured schedule included 
objective items to identify whether the participants were suffering from culture shock and also subjective items to investigate what feelings they might have and how they would do to deal with these problems. In the actual interviews, the mentioned schedule was used as a guideline in case the participants had more detailed and useful information that could be applied in the research. All interviews were done in Mandarin by the researcher, who was a friend and senior to all participants. Therefore, participants' real sentiments and culture shock symptoms could be elicited to the maximum extent.

The participant observations were conducted indoors (speaking courses in Language Center in Indonesia University of Education (UPI)) and outdoors (daily activities) in tandem with in-depth interviews. The observation session lasted for over two months, which allowed the researcher to build a holistic picture of participants' intercultural communicative competence and its insider-knowledge and presuppositions. During classroom observations, data collected from the daily lesson with its usual participants in real time under natural settings could constitute coherent "emic" world (Liu, 2013). In addition to that, the research was assisted by an Indonesian language teacher who created naturalistic intercultural communicative

Table 1. Eight participants of the research

\begin{tabular}{ccccccccc}
\hline & $\mathbf{1}$ & $\mathbf{2}$ & $\mathbf{3}$ & $\mathbf{4}$ & $\mathbf{5}$ & $\mathbf{6}$ & $\mathbf{7}$ & $\mathbf{8}$ \\
\hline Sex & $\mathrm{F}$ & $\mathrm{F}$ & $\mathrm{F}$ & $\mathrm{F}$ & $\mathrm{M}$ & $\mathrm{M}$ & $\mathrm{M}$ & $\mathrm{M}$ \\
\hline Age & 19 & 19 & 20 & 20 & 20 & 20 & 23 & 20 \\
\hline UKBI & 680 & 673 & 660 & 690 & 702 & 685 & 642 & 661 \\
\hline
\end{tabular}

\section{Data analysis}

Qualitative approach was adopted to explore and understand the meaning individuals ascribe to a social or human problem (Creswell, 2009), or in this case, culture shock. First, from the data obtained during indepth interviews (i.e. instances of culture shock symptoms) the key information was grouped under similar concepts then formed into categories, which were the basis of the hypothesis. Then, participants intercultural communicative competence manifested in conversations such as topics about dietary habits in China and Indonesia. The researcher used a loose checklist of preplanned observation categories that focused on students' culture shock symptoms and intercultural communicative competence, including four aspects of content, structure, language performance, and interaction. During outdoor observations, the researcher focused on culture shock influence on participants' verbal and nonverbal intercultural communicative behaviors through basic activities of daily living.

\section{Participants}

The research involved eight Chinese Indonesianlanguage students ( 4 males, 4 females) (see Table 1) who were sponsored by scholarship programs (University-to-university Program and China Scholarship Council) and had just begun their overseas study on September $4^{\text {th }}, 2017$ in UPI. They were all undergraduate students in a " $3+1$ " program which means three years' university in China (freshman year, sophomore year, and senior year) and one year's university studying in Indonesia (junior year). Their Indonesian Language Proficiency Test (UKBI) grades ranged from 642-702 (outstanding).

Table 2. Results of culture shock (objective items)

\begin{tabular}{|c|c|c|c|c|}
\hline \multirow[b]{2}{*}{ No. } & \multirow[b]{2}{*}{ Items } & \multicolumn{3}{|c|}{ Answers (percentage) } \\
\hline & & $\begin{array}{l}\text { Most of the } \\
\text { time }\end{array}$ & Sometimes & Never \\
\hline 1 & I miss my family members and friends in China. & $87.5 \%$ & $0 \%$ & $12.5 \%$ \\
\hline 2 & I find things in this new environment shocking or even disgusting. & $87.5 \%$ & $12.5 \%$ & $0 \%$ \\
\hline 3 & I feel strained when trying to adapt to this new culture. & $25 \%$ & & $2.5 \%$ \\
\hline 4 & $\begin{array}{l}\text { I would more like to communicate with my Chinese classmates } \\
\text { rather than with local people. }\end{array}$ & $25 \%$ & $62.5 \%$ & $12.5 \%$ \\
\hline 5 & I have a desire to escape from this new environment. & $25 \%$ & $62.5 \%$ & $12.5 \%$ \\
\hline \multicolumn{5}{|c|}{ 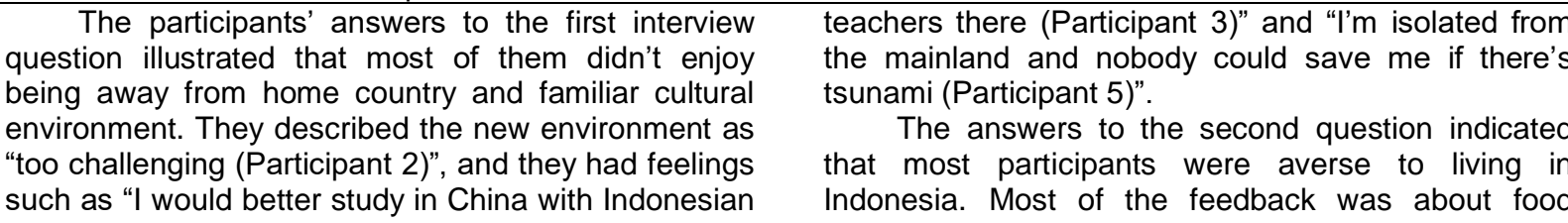 } \\
\hline
\end{tabular}

observations was analyzed in order to triangulate the hypothesis.

\section{FINDINGS AND DISCUSSION Culture shock is unavoidable}

The results of the five questions from in-depth interviews are giving below in Table 2 . The researcher further asked the participants who suffered from culture shock to give detailed instances and psychological descriptions on how they perceived and experienced culture shock. 
sanitation ("food was served on an unwashed leaf (Participant 1)" and "they eat with bare hands (Participant 4)") and living condition ("there was no hot bath nor shower (Participant 7)" and "there was a curfew time before 22:00 (Participant 8)"). Seven out of eight participants had moved from a "kos" (boarding house) to a villa next their campus and hired a housemaid to help with the cleaning and laundry.

The answers to the third question demonstrated that many participants were not confident or motivated when exposed to Indonesian social and cultural situations. To illustrate his opinions, Participant 6 explained that he found Indonesian taboos "way too superstitious". In the meantime, Participant 5 also argued that the religious system perplexed him as an atheist.

The answers to the fourth question showed that many participants had obstacles when engaging in communication with local people and chose to turn to fellow countrymen from China for consolation. There was a consensus amongst Participant $4,6,7$, and 8 that Indonesian people were accustomed to prying into private affairs of others, such as "do you have a boyfriend" or "when will you get married". Participant 2 shared her "awkward" experience that she was asked to take "selfie photos" by over twenty local tourists in a scenic spot in Indonesia. Participant 8 reported that he never wanted to be involved in a group discussion with Indonesian students because "I just don't get them, and vice-versa".

The answers to the fifth question indicated that the occurred culture shock was so strong that participants started to have second thoughts about studying aboard, even studying the Indonesian language. Participant 3, 5, and 8 mentioned that they initiated to skip class from time to time. Participant 5 specifically mentioned that he had trouble "giving a speech in front of the class because he couldn't master the Indonesian pragmatic habits". Participant 6 pointed out that "even though I was graded 'outstanding' on Indonesian written and listening competence, I'm barely an 'average' student when it comes to Indonesian speaking practice in class." Beyond that, it is worth mentioning that Participant 1 that had rather mild culture shock reactions was a Chinese Muslim who had the same belief system and semblable behavioral customs with the majority of Indonesian people.

To sum up the data collected from in-depth interviews, participants were all suffering from culture shock. They wanted to stay away from anxious foreign cultural environment as far as possible, and went to their Chinese classmates as a care-free shelter. As a matter of fact, previous research has suggested that communicating with same culture members is minimally helpful for intercultural adjustment (Lin, 2007). Participants need to remain an open heart to foreign cultures and build multicultural competence in order to survive in the age of globalization (Syhabuddin, 2014).

\section{Pragmatic failures in intercultural communication} The indoor participant observations were conducted in speaking courses, where the participants were asked to practice their communicative competence in roleplaying exercises in front of the class. The data were collected from each participant's three exercises (two dialogues and one speech). Table 3 elaborated the frequency of students' less satisfactory performance into a ranked order.

Table 3. Students' performance in communication practice

\begin{tabular}{cccc}
\hline Aspects & Description & Frequency & Percentage \\
\hline \multirow{2}{*}{ Content } & Incorrect descriptions on Indonesian culture & 4 & $50 \%$ \\
\cline { 2 - 4 } & Monotonous content & 4 & $50 \%$ \\
\hline \multirow{2}{*}{ Structure } & Failed to use fixed patterns in a speech \\
& (i.e. openings and endings) & 5 & $62.5 \%$ \\
\cline { 2 - 4 } & Unfamiliar with fixed expressions in greeting people & 3 & $37.5 \%$ \\
\hline Language & Reliance on translation & 6 & $75 \%$ \\
\hline Performance & Strong Chinese accent & 2 & $25 \%$ \\
\hline \multirow{2}{*}{ Interaction } & Reticence & 2 & $25 \%$ \\
\cline { 2 - 4 } & Low self-esteem & 5 & $62.5 \%$ \\
\cline { 2 - 4 } & No eye contact & 6 & $75 \%$
\end{tabular}

The teacher remarked that all participants demonstrated great ability in memorizing words and grammatical patterns. This was also confirmed in their UKBI tests. Nevertheless, it can be seen from the classroom observations results that participants were less competent when it came to oral communication.

The outdoor observations complemented the classroom observations by revealing more examples of culture shock symptoms in a naturalistic intercultural communication environment where participants need to apply what they learned in class to real pragmatic scenarios. The researcher found that participants acted quite intrigued when facing the exotic Indonesian culture for the first time. Whereas when taking part in the cultural activities in person, the participants were sometimes startled even overwhelmed by the immense and endless culture shock aftermath. For instance, Participant 8 once used a word "kemaluan" to express his feelings of embarrassment, because he had learned that the word "malu" which stood for "embarrassing" in Indonesian language, and the circumfix "ke-an" 
referring to a state or condition. However, he was laughed at by his Indonesian friends since the word "kemaluan" actually means "genitals" in Indonesian language. Participant 8 reported that he couldn't break out of that awkwardness, because not only was it a subtly inappropriate slip of tongue, but also an impossible mistake made by him as a student majored in Indonesian language.

Pragmatic fault aside, seven out of eight participants' behaviors illustrated that they were fed up with constant "basa-basi (small talks)". For instance, Participant 5 was often asked about her marriage status, while Participant 7 was often asked about his whereabouts. They argued that even though they well acknowledged that "small talks" was part of Indonesian culture, it was still annoying to be frequently pried into.

Moreover, another prominent culture shock symptoms in intercultural communication was that the participants didn't know how to refuse in case not to offend the couterpart. Participant 1 reported that she didn't know how to reject a "pengamen (busker)" begging for money without offending him or her, notwithstanding she was not a submissive type of person.

Other than that, participants came across difficulties when seeking for solutions of intercultural communicative incompetence. For example, Participant 6 recited that his Indonesian friends found his oral expressions weird because his diction was "too formal" when engaging in a daily conversation, that he should use more "bahasa gaul (social language or slang)". Nonetheless, he wasn't taught any social language on campus, nor could he find appropriate self-educated materials.

The results of indoor participant observations show that intercultural communicative incompetence may leave deep and long-lasting psychological impacts on participants. In the meantime, academic educational system was not a perfection to aid students in foreign cultural environment. Recently, academic adaptation has been found to be a core issue of intercultural adaptation (Yu, 2009; Zeng, 2006), which is closely and positively related to sociocultural adaptation (Yu, 2010). Therefore, Yu (2009) suggested that academic adaptation should be taken as one important facet to study intercultural adaptation. However, academic adaptation, emphasizing college impact on students' positive learning outcome in higher education (Tinto, 1993), has unfortunately been largely ignored in the literature and research of study abroad students' intercultural adaptation.

\section{Intercultural adaptation and adjustment}

The last interview in the research was conducted four months later (December $30^{\text {th }}, 2017$ ) since participants' first time landing on Java Island. Six out eight participants reported that they had made adaptation and adjustment in intercultural communication.
Intercultural adjustment and adjustment refer to a long-term process in which new comers adjust to and finally feel comfortable in a new cultural environment (Kim, 2001). Through the improvement and remodeling of communicative competence, participants had achieved remission of culture shock symptoms (based on the same interview schedule aforementioned). This may be exemplified by excerpts from four participants.

Participant 3 reported that she was assisted by an Indonesian student after class with her language ability. "She's not only a tutor, but also a friend of mine. She even invited me to her house and showed me how to cook Indonesian cuisines. She practically uses only Indonesian language since she isn't fluent in English. For sure, I cannot understand every word, but I can grasp the main idea and guess the whole meaning. I think this is the reason why my Indonesian has gained much improvement." Participant 4 reported that she started to watch Indonesian soap operas and viral videos on YouTube. "I'm not an outdoor person, so I turn to Internet to browse the outside world. I didn't know that Indonesian people were this funny and talented. I also learned many catchwords in Indonesian language and common words in dialects. My Indonesian friends were amazed when they heard me saying 'hatur nuhun' ('thank you' in Sundanese dialect) instead of 'terima kasih' ('thank you' in standard Indonesian language). I feel that I'm bridging the distance between Indonesia and myself." Participant 7, who used to dislike Indonesian small talks and alienate himself from Indonesian people, reported that he was more willing to participate in class discussions and meeting Indonesian friends. "I searched online get to the root of the small-talk culture in Indonesia. It turns out that many foreigners have the same complains like mine. I also found out that the intention of small talks was not to pry into privacy, but more of a custom of socializing. Now, I am the one who addresses a small talk to my Indonesian friends." Participant 1, who was the least culture-shockeffected participant in the research, had joined in local student entrepreneur club and traveled to several major cities in Indonesia. She claimed that she had "fallen in love with Indonesian and never want to leave." The adaptation and adjustment in intercultural communication was made because participants changed their perspectives on Indonesian culture, and made a further and more particular knowledge of its content. Some of the participants admitted that at first they were compelled to adapt the foreign cultural situation so to survive in Indonesia, but they were satisfied with what they had experienced and achieved.

Simultaneously, Participant 5 and Participant 8 reported that they were still reluctant to blend in Indonesian community. They both showed low selfesteem in intercultural communication. "It is funny that my English is getting better in this non-Englishspeaking country, because I always hang out with 
foreign friends (Indonesian excluded)," reported Participant 5. "I tried to get involved in Indonesian community, but I yielded because it wasn't as easy as I expected. Now, all I have to do is to struggle through the rest of the semester then fly back home. My main task here is to earn enough credits, I suppose."

It can be drawn from the interviews that selfconfidence, self-efficacy and self-motivation play key roles in decreasing anxiety and overcoming culture shock issues (Saylag, 2013). People with high selfefficacy usually believe that they have abilities to perform tasks well. Lack of confidence is one of the most important reasons for failure. Although different people use various techniques to try to minimize the impact of culture shock, it seems that a high degree of self-confidence and optimism may be among the most effective. However, as Aronson and Sues have indicated, dealing with many people undergoing a cultural transition can be difficult since people's personalities are diverse. Many people are optimistic and self-confident naturally, but others may be less so and in fact may have a more pessimistic view of life (Aronson \& Sues, 1987). Thus, moderate selfconfidence and an optimistic mood are necessary to help people deal with culture shock. What should always be emphasized in supporting people through this process is that it is a normal stage of cultural adjustment rather than threat, and should be seen and dealt with as a new challenge (Saylag, 2013).

\section{ABC framework applied to intercultural communicative competence teaching}

A pattern was concluded from the participants' data that incompetence of intercultural communication was regarded as both the cause and consequence to culture shock in this study case. In intercultural communication, being unaware of each other's respective social and cultural tradition, the interlocutors may participate in the communication with their own cultural values and use their own cultural systems to interpret the new situations they experience (Huang, 2014). This is particularly pivotal and prominent for students majored in foreign languages. Without the improvement on intercultural communicative competence, the mentioned culture shock phenomenon is but an infinite loop that might cause acculturative stress (Berry, Kim, Minde, \& Mok, 1987), adjustment strain (Crano \& Crano, 1993), and even permanent damage (Bratt-Paulston, 1992).

Considering the great culture shock symptoms and intercultural communicative barriers faced by the Chinese Indonesian-language students, mediation and scaffolding are needed from teachers and the surrounding community (Daniels, 2005). The participants in the research expressed concerns about their language learning and desired more learning support from the university. Contemporary theories and approaches to culture shock are currently based on its affective, behavioral, and cognitive components, referred to as the $A B C$ framework of culture shock
(Ward, Bochner, \& Furnham, 2001). Applying ABC framework to enhancing intercultural communicative competence might be a workable model in language teaching.

First, the affect aspect. Teachers or supervisors should be sensitively aware of the individuals who are undergoing the culture shock process. Teachers should use examples of similarities in between Chinese and Indonesian cultures to gradually draw students' attention and interest into intercultural communication study. After affection basis is built, teachers should point out the contrast in between Chinese and Indonesian cultures, then identify and explain the significance of life changes during crosscultural transitions, the appraisal of these changes (Lombard, 2014), and the application of coping strategies so as to help students grow confidence in dealing with inherently stressful situations. Besides, teachers are required to use Indonesian language as the language of instruction to build an immersion teaching environment. Translation method is not recommended as it may cause students' reliance on mother tongue.

Second, the behavior aspect. This is a stage of cultural learning as an understanding of the attitude and behavior in the host country with regard to social skills (Furnham \& Bochner, 1986). Indirect approach (transfer approach) can be used in intercultural communicative training (Goh, 2013). It focuses on the production of speech rather than isolated structure accuracy, pronunciation, or language forms, which involves students in practicing spoken language for special purposes. In order to help Chinese students overcome the culture shock issues, teachers may assign topics incorporated Indonesian cultural context or background with several clues of cultural features into the whole process of language teaching. After that, teachers should further assess students' verbal and nonverbal communicative competence. Finally, teachers should give meaningful feedback to students on their behaviors to encourage and improve their achievements.

Third, the cognitive aspect. This aspect is anchored in the theory of social identification where identity is the fundamental issue for cross-cultural (Ward, Bochner, \& Furnham, 2001), which means these students that have encountered and traversed cultural differences should define new perspectives of identity that enable them to perform roles such as being academically successful (Pham \& Saltmarsh, 2013). Teachers should encourage and motivate students to apply what they have learned in class to experiencing real-time cultural activities. In the meantime, teachers should provide adequate local peer support and communication channels for students. This could accelerate the alleviation of "shocking" symptoms and build students' self-esteem in intercultural communication.

\section{Implications for students}


Ward, Bochner, and Furnham (2001) argued out that international students are probably the most intensely studied group in the culture shock literature, which indicates that culture shock is frequently experienced, normal, and unavoidable. Students should recognize that there are many approaches to alleviate the mentioned issue. At the same time, students should reconceptualize abroad study. As being proved in the subsection "Intercultural adaptation and adjustment", one should be bold and confident to take responsibility of their own communicative development and choose to participate more in a foreign cultural environment (Lantolf \& Johnson, 2007). Accordingly, a self-reliant attitude needs to be established so that students can survive in a different and unfamiliar cultural environment.

\section{CONCLUSION}

This research explored culture shock issues encountered by Chinese Indonesian-language students when studying abroad in Indonesia and attempted to investigate the causes from the perspective of intercultural communicative competence by adopting qualitative approach. Through analysis of eight Chinese students' cultural experiential accounts in a span of three months, and two months' indoors and outdoors observations, the pattern is shown that Chinese Indonesian-language students had suffered from culture shock. They had shown uncertainty, anxiety, stress, and alienation through the concretization of intercultural communicative incompetence. It is found that they had tried adapting and adjusting themselves to intercultural communicative system, including looking for peer relationship, augmenting extracurricular involvement, improving language proficiency, and interacting with local people. But not all of the participants had achieved remission of culture shock symptoms. The two most heavily affected participants were not confident or motivated enough to take a step out from their comfort zone to foreign cultural community.

Based on the findings, the researcher suggests that a self-restraint attitude should be built so that students can survive in a different and unfamiliar cultural environment. It is also suggested that teachers should encourage and support students to frequently engage in intercultural communions, and the educational institutions should provide peer support and develop certain media and methods on improving intercultural communicative competence to help students alleviate culture shock symptoms.

This research, as most do, was conducted with a number of limitations. First, the interviews were done in Mandarin then translated into English. Therefore, it is possible that the context meaning was not delivered intactly. Second, although highly unlikely, it remains a possibility that students who participated in the research were the only ones who had experienced culture shock in the research scope. It is suggested that further research might focus on teaching media and methods development or how to well prepare students who are going to study abroad both in culture and communication.

\section{REFERENCES}

Aronson, R., \& Sues, H. D. (1987). The palaeoecological significance of an anachronistic ophiuroid community, in Kerfoot, W. C., \& Sih, A. (Eds.) Predation: direct and indirect impacts on aquatic communities (355366). Hanover, NH: University Press of New England.

Barron, A. (2006). Learning to say 'you' in German: the acquisition of sociolinguistic competence in a study abroad context, in DuFon, M. A., \& Churchill, E. (Eds.): Language learners in study abroad contexts (59-88). Clevedon: Multilingual Matters.

Berry, J. W., Kim, U., Minde, T., \& Mok, D. (1987). Comparative studies of acculturative stress. International Migration Review, 21, 491-511.

Bratt-Paulston, C. (1992). Linguistic and communicative competence: topics in ESL. Clevedon: Multilingual Matters.

Cetinavci, U. R. (2012). Intercultural communicative competence in ELT. World Conference on Educational Sciences 2012. Procedia - Social and Behavioral Sciences, 46, 3445-3449.

Chapdelaine, R. F., \& Alexitch, L. R. (2004). Social skills difficulty: model of culture shock for international graduate students. Journal of College Student Development, 45, 167-184.

Charles, H., \& Stewart, M. A. (1991). Academic advising of international students. Journal of Multicultural Counseling and Development, 19, 173-181.

Chen, C. H., \& Zimitat, C. (2006). Understanding Taiwanese students'decision-making factors regarding Australian international higher education. International Journal of Educational Management, 20(2), 91-100.

Crano, S. L., \& Crano, W. D. (1993). A measure of adjustment strain in international students. Journal of Cross-Cultural Psychology, 24, 267-283.

Creswell, J. W. (2009). Research design qualitative, quantitative, and mixed methods approaches (3rd ed.). Thousand Oaks, CA Sage Publications.

Daniels, H. (2005). An introduction to Vygotsky (2nd ed.). London: Routledge.

Freed, B. F. (1995). What makes us think that students who study abroad become fluent? In Freed, B. F. (Eds.), Second language acquisition in a study abroad context (123-48). Amsterdam: Benjamins..

Goh, C. C. M. (2013). Globalization and teacher development for spoken english instruction. 
Indonesian Journal of Applied Linguistics, 3(1), 29-38.

Guilherme, M. (2000). Intercultural competence. in, Byram M. S. (Eds.), Routledge M., Encyclopedia of language teaching and learning (298-300). London and New York: Routledge Taylor and Francis Group.

$\mathrm{Hu}, \mathrm{X}$. (2008). The culture shock that Asian students experience in immersion education. Changing English, 15(1), 101-105.

Guanipa, C. (1998). Culture shock. Deptartment of Counseling and School Psychology, San Diego State University.

Huang, Y. (2014). Constructing intercultural communicative competence framework for English learners. Cross-Cultural Communication, 10(1), 97-101.

Khawaja, N. G., \& Dempsey, J. (2007). Psychological distress in international university students: an Australian study. Australian Journal of Guidance and Counselling, 17, 13-27.

Lantolf, J. P., \& K. E. Johnson. (2007). Extending Firth and Wagner's (1997) ontological perspective to L2 classroom praxis and teacher education. The Modern Language Journal, 91(5), 875-90.

Lewthwaite, M. (1996). A study of international students' perspectives on cross-cultural adaptation. International Journal for the Advancement of Counselling, 19, 167-185.

Liddicoat, A. (2009). Communication as culturally context practice: a view from intercultural communication. Australian Journal of Linguistics. 29(1), 115-133.

Lin, C. (2007). Culture shock and social support: an investigation of a chinese student organization on a us campus. Journal of Intercultural Communication Research, 35(2), 117-137.

Liu, C. (2013). From language learners to language users: a study of Chinese students in the UK. International Journal of Applied Linguistics. 23(2), 123-143.

Lin, J. C. G., \& Yi, J. K. (1997). Asian international students' adjustment: Issues and program

suggestions. College Student Journal, 31, 473-479.

Lombard, C. N. (2014). Coping with anxiety and rebuilding identity: a psychosynthesis approach to culture shock. Counselling Psychology Quarterly, 27(2), 174-199.

Lukyanovaa, N., Daneykina, Y., \& Daneikina, N. (2015). Communicative competence management approaches in higher education. Procedia - Social and Behavioral Sciences, 214 (2015), 565-570.

Mumford, D. B. (1998). The measurement of culture shock. Social Psychiatry and Psychiatric Epidemiology. 33(4), 149-154.

Naysmith, J., \& S. Corcoran. (2001). Culture shocks: immersion education at the University College Chichester. Language and Cultural Immersion. The Hong Kong Institute of Education.
Peacock, J. (1988). The anthropological lens: harsh light, soft focus. Cambridge: Cambridge University Press.

Pham, L., \& Saltmarsh, D. (2013). International students' identities in a globalized world: Narratives from Vietnam. Journal of Research in International Education, 12, 129-141.

Rinehart, N. (2002). Utalitarian or idealist? Frameworks for assessing the study abroad experience. in Grünzweig, W., \& Rinehart, N. (Eds.), Rockin' in Red Square: critical approaches to international education in the age of cyberculture (75-84). Münster: Lit Verlag.

Ryan, J., \& Carroll, J. (2005). Canaries in the coalmine: international students in western universities. in Carroll, J. \& Ryan, J. (Eds.), Teaching international students. Abingdon: Routledge.

Saylag, R. (2013). Culture Shock an obstacle for EFL learners. 4th World Conference on Psychology, Counselling and Guidance 2013. Procedia Social and Behavioral Sciences, 114(2014), $533-537$.

Segalowitz, N., \& Freed, B. F. (2004). Context, contact, and cognition in oral fluency acquisition: learning Spanish at home and study abroad contexts. Studies in Second Language Acquisition, 26(2), 173-99.

Smith, J. A., Harré, R., \& Langenhove, L. (1995). Rethinking methods in psychology. Sage Publications.

Spencer, L. \& Spencer, S. (1993). Competence at work: a model for superior performance. New York: Wiley.

Syihabuddin. (2014). Merespon konvergensi peradaban dunia melalui bikulturalisme dan internalisasi nilai budaya dalam konteks pendidikan tinggi. Seminar Nasional Forum Pimpinan Pascasarjana LPTK Indonesia 2014.

Taguchi, N. (2008). Cognition, language contact, and the development of pragmatic comprehension in a study-abroad context. Language Learning, 58(1), 33-71.

Ward, C. A., Bochner, S., \& Furnham, A. (2001). The psychology of culture shock. Routledge, Medical.

Wiseman, R. L. (2002). Intercultural communication competence, in Gudykunst, W. B. \& Mody B. (Eds.), Handbook of international and intercultural communication (2nd ed.), (207224). Thousand Oaks, CA: Sage.

Yang, M., Webster, B., \& Prosser, M. (2011). Travelling a thousand miles: Hong Kong Chinese students' study abroad experience. International Journal of Intercultural Relations, 35(1), 69-78.

$\mathrm{Yu}$, B. (2009). Cross-cultural adaptation and second language acquisition: a study of international 
students in universities of the People's Republic of China. Saarbruecken: VDM Verlag.

$\mathrm{Yu}$, B. (2010). Learning Chinese abroad: the role of language attitudes and motivation in the adaptation of international students in China.
Journal of Multilingual and Multicultural Development, 31(3), 301321.

Zhang, W. (2014). A brief study on culture shock over overseas students and the solution to new cultural environments. Overseas English, 23, 219-220. 